УДК 327

Научная статья

DOI 10.18101/2306-630X-2020-1-46-53

\title{
ИНСТИТУТЫ ГУМАНИТАРНОГО СОТРУДНИЧЕСТВА МЕЖДУ РОССИЙСКОЙ ФЕДЕРАЦИЕЙ И РЕСПУБЛИКОЙ КАЗАХСТАН
}

\author{
(C) Муратшина Ксения Геннадьевна \\ кандидат исторических наук, доцент, \\ Уральский федеральный университет \\ имени первого Президента России Б. Н. Ельцина \\ Россия, 620002, г. Екатеринбург, ул. Мира, 19 \\ ksenia.muratshina@urfu.ru
}

\begin{abstract}
Аннотация. В статье анализируется институциональная структура двустороннего сотрудничества между Российской Федерацией и Республикой Казахстан в гуманитарной сфере, то есть связей в таких областях, как культура, образование, наука, информация и массовые коммуникации, спорт, туризм и работа с молодежью. На основе изучения процессов межгосударственного гуманитарного сотрудничества за последнее десятилетие (2010-2020 гг.) автором выделены и рассмотрены как государственные, так и негосударственные институты взаимодействия: контакты отраслевых ведомств (министерств и агентств), дипломатических представительств, местных органов власти, общественных движений, некоммерческих организаций, диаспор. В качестве источников использованы двусторонние дипломатические документы, официальные отчеты органов государственной власти, актуальные новостные публикации российских и казахстанских СМИ, материалы общественных организаций.
\end{abstract}

Ключевые слова: Россия; Казахстан; государство; общество; международные отношения; гуманитарное сотрудничество; евразийская интеграция.

Благодарность: исследование выполнено за счет гранта Российского научного фонда (проект № 19-78-10060 «Гуманитарное сотрудничество между Россией и странами постсоветской Центральной Азии: институты, содержание, оиенка социальной эффективности»).

\section{Для цитирования}

Муратшина К. Г. Институты гуманитарного сотрудничества между Российской Федерацией и Республикой Казахстан // Евразийство и мир. 2020. № 1. С. 46-53.

Россия и Казахстан - государства-соседи и союзники, стоящие у истоков процесса современной евразийской интеграции [1-6] и развивающие интенсивное двустороннее взаимодействие по всем направлениям [7-10]. Одной из важных сфер межгосударственных взаимоотношений является гуманитарное сотрудничество ${ }^{1}$, которое призвано удовлетворять запрос на взаимодействие между наро-

\footnotetext{
${ }^{1}$ По Соглашению о гуманитарном сотрудничестве стран - участников Содружества Независимых Государств, в гуманитарную сферу входят следующие области взаимодействия: культура, образование, наука, информация и массовые коммуникации, спорт, туризм и работа с молодежью. Подробнее см.: Соглашение о гуманитарном сотрудничестве государств-участников СНГ [Электронный ресурс] // Межгосударственный фонд гуманитар-
} 
Муратшина К. Г. Институты гуманитарного сотрудничества между Российской Федерацией и Республикой Казахстан

дами дружественных стран, обеспечивать прочную социальную базу партнерства и способствовать росту взаимопонимания в условиях непростой международной обстановки. В данной статье будет рассмотрено, через какие государственные и общественные институты осуществлялись гуманитарные контакты между РФ и РК на двустороннем уровне в последнее десятилетие.

Для начала рассмотрим государственные институты гуманитарного сотрудничества двух стран. Помимо стандартных для постоянно контактирующих стран регулярных встреч руководителей высшего и высокого уровня (глав государств, глав правительств, министров иностранных дел), где обсуждаются все вопросы двусторонних отношений, за годы взаимодействия сложились связи между российскими и казахстанскими отраслевыми ведомствами. Например, это Министерство культуры РФ и Министерство культуры и спорта РК, Федеральное агентство по делам молодежи РФ (Росмолодежь) и Министерство информации и общественного развития РК, Федеральное агентство по делам национальностей РФ и Министерство информации и общественного развития РК, министерства образования двух стран. Между ними согласовываются принципы работы по соответствующим направлениям, реализуются совместные программы, проекты, форумы ${ }^{1}$.

Также на правительственном уровне с 1999 г. действует Межправительственная комиссия по сотрудничеству между РФ и РК, в компетенцию которой в том числе

ного сотрудничества государств-участников СНГ. 2006. URL: http://mfgs-sng.org/sgs/gum _ sotr/ (дата обращения: 08.12.2019).

${ }^{1}$ Подписано соглашение о культурном сотрудничестве между Россией и Казахстаном [Электронный ресурс] // Министерство культуры РФ. 06.10.2017. URL: https://www.mkrf.ru/press/ news/podpisano-soglashenie-o-sotrudnichestve-v-oblasti20171006162212/ (дата обращения: 23.02.2020); В Москве впервые пройдёт Российско-Казахстанский молодежный форум [Электронный ресурс] // Росмолодежь. 14.11.2016. URL: https://fadm.gov.ru/presscenter/ announcements/215 (дата обращения: 23.02.2020); В Костанае пройдет Фестиваль казахстанскороссийского молодежного сотрудничества [Электронный ресурс] // Росмолодежь. 15.05.2019. URL: https://fadm.gov.ru/news/47735 (дата обращения: 23.02.2020); В Омске открылся Форум молодежных лидеров России и Казахстана [Электронный ресурс] // Телекомпания «Мир». 06.11.2019. URL: https://mir24.tv/news/16384842/v-omske-otkrylsya-forum-molodezhnyh-liderovrossii-i-kazahstana (дата обращения: 23.02.2020); В Москве определили перспективы развития российско-казахстанских молодежных отношений [Электронный ресурс] // Росмолодежь. 06.02.2020. URL: https://fadm.gov.ru/news/53175 (дата обращения: 23.02.2020); Руководитель ФАДН России Игорь Баринов посетил с рабочим визитом Республику Казахстан [Электронный ресурс] // Федеральное агентство по делам национальностей РФ. 11.11.2016. URL: http://fadn. gov.ru/news/2016/11/11/2971-rukovoditel-fadn-rossii-igor-barinov-posetil-s-rabochim-vizitomrespubliku-kazahstan (дата обращения: 23.02.2020); Соглашение о сотрудничестве в области образования между Министерством образования Российской Федерации и Министерством образования Республики Казахстан (подписано 12 февраля 1993 г.) [Электронный ресурс] // Гарант. URL: http://base.garant.ru/1119629/ (дата обращения: 23.02.2020); Соглашение между Министерством образования и науки Российской Федерации и Министерством образования и науки Республики Казахстан об условиях деятельности общеобразовательных учреждений с казахским языком обучения города Байконура [Электронный ресурс] // Портал «Международное право». URL: http://www.conventions.ru/view_base.php?id=1607 (дата обращения: 23.02.2020). 
входят «анализ состояния российско-казахстанского сотрудничества, выявление наиболее перспективных его направлений и путей совершенствования форм взаимодействия», «наблюдение за ходом выполнения соглашений», «подготовка и согласование договоров и программ торгово-экономического, научно-технического и гуманитарного сотрудничества», «координация деятельности органов исполнительной власти, предприятий, организаций и физических лиц в целях развития торгово-экономического, научно-технического и гуманитарного сотрудничества между двумя странами» ${ }^{1}$. Заседания Комиссии проводятся не реже двух раз в год поочередно в обеих странах, на них обсуждаются вопросы как торгово-экономического, так и гуманитарного сотрудничества ${ }^{2}$. Также широкий круг вопросов обсуждается в ходе взаимодействия органов законодательной власти двух стран - межпарламентских контактов ${ }^{3}$.

Далее, следует упомянуть деятельность дипломатических учреждений РФ и РК. Помимо посольств России и Казахстана действуют четыре консульских учреждения РК в РФ (Генконсульства в Санкт-Петербурге и Казани, консульства в Астрахани и Омске $)^{4}$ и три - РФ в РК (Генконсульства в Алма-Ате, Уральске и Усть-Каменогорске) $)^{5}$. В Нур-Султане также работает Российский центр науки и культуры, являющийся представительством Федерального агентства РФ по делам Содружества Независимых Государств, соотечественников, проживающих за рубежом, и по международному гуманитарному сотрудничеству (Россотрудничества) ${ }^{6}$. Именно эти учреждения

${ }^{1}$ Соглашение между Правительством Российской Федерации и Правительством Республики Казахстан о Межправительственной комиссии по сотрудничеству между Российской Федерацией и Казахстаном [Электронный ресурс] // Электронный фонд правовой и нормативно-технической документации. URL: http://docs.cntd.ru/document/901748489 (дата обращения: 23.02.2020).

${ }^{2}$ В Москве состоялось заседание Межправительственной комиссии по сотрудничеству между Казахстаном и Россией [Электронный ресурс] // Automan.kz. 28.11.2010. URL: http:// www.automan.kz/214649-v-moskve-sostojalos-zasedanie.html (дата обращения: 23.02.2020); Игорь Шувалов принял участие в заседании Межправительственной комиссии по сотрудничеству между Россией и Казахстаном [Электронный ресурс] // Правительство РФ. 17.11.2017. URL: http://m.government.ru/news/30166/ (дата обращения: 23.02.2020); XX заседание Межправительственной комиссии Казахстан - Россия состоялось в Казани [Электронный ресурс] // Агентство «Хабар». 29.10.2018. URL: https://24.kz/ru/news/policy/ item/274358-xx-zasedanie-mezhpravitelstvennoj-komissii-kazakhstan-rossiya-sostoyalos-v-kazani (дата обращения: 23.02.2020).

${ }^{3}$ Казахстан - Россия: стратегическое партнерство [Электронный ресурс] // Мажилис Парламента Республики Казахстан. 27.01.2014. URL: http://www.parlam.kz/ru/mazhilis/newsdetails/id13170/1/15 (дата обращения: 23.02.2020).

${ }^{4}$ Консульские учреждения Республики Казахстан в Российской Федерации [Электронный ресурс] // Посольство Республики Казахстан в Российской Федерации. URL: https:// kazembassy.ru/rus/konsulstvo/kons_uchr/ (дата обращения: 23.02.2020).

${ }^{5}$ Консульские учреждения [Электронный ресурс] // Посольство Российской Федерации в Республике Казахстан. URL: http://www.rfembassy.kz/tm/russian_mission_in_kazakhstan/ konsulskie uchrezhdenija/ (дата обращения: 23.02.2020).

${ }^{6}$ Российский центр науки и культуры [Электронный ресурс] // Посольство Российской Федерации в Республике Казахстан. URL: http://www.rfembassy.kz/tm/russian_mission_in 
Муратшина К. Г. Институты гуманитарного сотрудничества между Российской Федерацией и Республикой Казахстан

проводят большую часть мероприятий в сфере культурных обменов и содействуют прямым контактам заинтересованных организаций двух стран ${ }^{1}$.

На региональном уровне гуманитарная сфера также является предметом сотрудничества государственных структур. Примечательно, что это характерно не только для приграничных регионов. Местными органами власти РФ и РК заключаются соглашения, организуются тематические мероприятия (например, Дни культуры, молодежные форумы и фестивали) $[11]^{2}$. Мероприятия носят не только двусторонний характер, часть из них - международные. На многие всероссийские форумы и конференции с международным участием приглашаются представители Казахстана. Во многих случаях региональные органы власти работают в контакте с неправительственными организациями ${ }^{3}$.

kazakhstan/rossotrudnichestvo/ (дата обращения: 23.02.2020); Российский центр науки и культуры в Нур-Султане [Электронный ресурс]. URL: http://kaz.rs.gov.ru/ru (дата обращения: 23.02.2020).

${ }^{1}$ Культурно-гуманитарное сотрудничество Казахстана и России в 2019 году [Электронный ресурс] // Посольство Республики Казахстан в Российской Федерации. URL: https:// kazembassy.ru/rus/dvustoronnee_sotrudnichestvo/kulturno-gumanitarnoe_sotrud/ (дата обращения: 23.02.2020).

${ }^{2}$ В Пензенской области состоится межрегиональный молодежный инновационный форум «Светлая поляна 2010 - Территория успеха» [Электронный ресурс] // Росмолодежь. 04.10.2010. URL: https://fadm.gov.ru/news/18540 (дата обращения: 23.02.2020); Стартовал IV Рязанский открытый всероссийский фестиваль детских и молодежных театральных коллективов «КАРУСЕЛЬ 2010» [Электронный ресурс] // Росмолодежь. 07.10.2010. URL: https://fadm.gov.ru/news/18569 (дата обращения: 23.02.2020); Уфа подвела итоги года в сфере молодежной политики [Электронный ресурс] // Росмолодежь. 24.02.2014. URL: https://fadm.gov.ru/news/23616 (дата обращения: 23.02.2020); Зауральская делегация начинает работу на Международном молодежном фестивале [Электронный ресурс] // Росмолодежь. 25.08.2016. URL: https://fadm.gov.ru/news/31080 (дата обращения: 23.02.2020); В Оренбурге стартовал финал Евразийского фестиваля студенческого творчества «На Николаевской 2018» [Электронный ресурс] // Росмолодежь. 24.04.2018. URL: https://fadm.gov.ru/news/41303 (дата обращения: 23.02.2020); Форум Сибирского федерального округа «Алтай. Территория развития» стартует в воскресенье [Электронный ресурс] // Росмолодежь. 09.06.2019. URL: https://fadm.gov.ru/presscenter/announcements/538 (дата обращения: 23.02.2020); Партнерский диалог Свердловской области и Казахстана продолжает активно развиваться [Электронный pecypc] // Правительство Свердловской области. 18.06.2019. URL: http://midural.ru/news/ vministerstvah/document149923/ (дата обращения: 23.02.2020); Омский РИТМ вновь соберет активную молодежь [Электронный ресурс] // Росмолодежь. 25.06.2019. URL: https://fadm. gov.ru/news/48776 (дата обращения: 23.02.2020).

${ }^{3}$ Приграничное сотрудничество [Электронный ресурс] // Росмолодежь. 06.04.2015. URL: https://fadm.gov.ru/news/25204 (дата обращения: 23.02.2020); В Оренбурге дали старт российско-казахстанскому молодежному форуму «Мы + Біз» [Электронный ресурс] // Росмолодежь. 20.04.2017. URL: https://fadm.gov.ru/news/34979 (дата обращения: 23.02.2020); Свердловские некоммерческие организации будут укреплять народную дипломатию [Электронный ресурс] // Правительство Свердловской области. 22.07.2019. URL: http://midural. ru/news/list/document152060/ (дата обращения: 23.02.2020); Зарубежные гуманитарные проекты свердловских НКО получили высокую оценку со стороны российских соотечественников [Электронный ресурс] // Правительство Свердловской области. 25.12.2019. URL: http://midural.ru/news/style/document160030/ (дата обращения: 23.02.2020); Екатерин- 
Теперь обратимся к выделению негосударственных институтов, которых со временем в российско-казахстанском гуманитарном взаимодействии становится все больше. Первыми здесь следует назвать механизмы все более интенсивного взаимодействия общественных организаций из РФ и РК - от молодежных и волонтерских движений ${ }^{1}$, представителей СМИ и медиабизнеса ${ }^{2}$ до студенческих отрядов ${ }^{3}$, турклубов ${ }^{4}$ и команд КВН ${ }^{5}$. Далее, регулярно ведутся и затрагивают в том числе вопросы гуманитарного сотрудничества контакты политических партий двух стран 6 . Имеются связи между общественными организациями двух стран в области спорта ${ }^{7}$.

бург: Как донести до молодежи память о войне? [Электронный ресурс] // Урал - Евразия. 17.02.2020. URL: http://ural-eurasia.ru/annonces/22-discussions/1384-ekaterinburg-kakdonesti-do-molodezhi-pamyat-o-vojne (дата обращения: 23.02.2020).

${ }^{1}$ Молодежь региона приняла участие в онлайн-конференции «Мир без войны» [Электронный ресурс] // Росмолодежь. 18.11.2016. URL: https://fadm.gov.ru/news/32454 (дата обращения: 23.02.2020); Молодежь Оренбуржья проведет флешмоб, посвященный реке Урал [Электронный ресурс] // Росмолодежь. 20.07.2017. URL: https://fadm.gov.ru/news/36717 (дата обращения: 23.02.2020).

2 Восьмой форум европейских и азиатских медиа пройдет в Москве [Электронный ресурс] // Роспечать. 03.11.2015. URL: http://fapmc.ru/rospechat/newsandevents/media/2015/11/ item2.html (дата обращения: 23.02.2020); В парке «Зарядье» состоится медиафорум «Пространство Евразии» [Электронный ресурс] // Роспечать. 24.04.2019. URL: http://fapmc.ru/ rospechat/newsandevents/media/2019/04/item13.html (дата обращения: 23.02.2020).

3 «Снежный десант» международного класса [Электронный ресурс] // Росмолодежь. 27.01.2020. URL: https://fadm.gov.ru/news/52968 (дата обращения: 23.02.2020).

${ }^{4}$ Юные туристы со всей России встретились на Южном Урале [Электронный ресурс] // Росмолодежь. 07.08.2019. URL: https://fadm.gov.ru/news/49648 (дата обращения: 23.02.2020).

${ }^{5}$ Первая игра сезона Омской региональной лиги КВН [Электронный ресурс] // Росмолодежь. 24.02.2015. URL: https://fadm.gov.ru/news/25105 (дата обращения: 23.02.2020); «Кубок Зауралья» разыграют среди самых музыкальных команд КВН [Электронный ресурс] // Росмолодежь. 15.12.2016. URL: https://fadm.gov.ru/news/32951 (дата обращения: 23.02.2020); В Челябинске определили четвертьфиналистов открытой обучающей лиги КВН [Электронный ресурс] // Росмолодежь. 24.03.2017. URL: https://fadm.gov.ru/news/34431 (дата обращения: 23.02.2020).

${ }^{6}$ «Единая Россия» встретилась с делегацией казахской партии «Нур Отан» [Электронный ресурс] // Фракция «Единая Россия» в Государственной Думе Федерального Собрания РФ. 23.06.2015. URL: http://duma-er.ru/video/edinaya-rossiya-vstretilas-s-delegatsieykazakhskoy-partii-nur-otan/ (дата обращения: 23.02.2020); В Омске состоялась встреча ведущих партий России и Казахстана [Электронный ресурс] // Посольство Республики Казахстан в Российской Федерации. 04.11.2019. URL: https://kazembassy.ru/rus/press_centr/ novosti/?cid=0\&rid=3616 (дата обращения: 23.02.2020); В Казахстане завершилась работа семинар-совещания Коммунистических партий стран Азии [Электронный ресурс] // Коммунистическая партия Российской Федерации. URL: https://kprf.ru/kpss/190140.html (дата обращения: 23.02.2020); Члены Чувашского рескома КПРФ встретились с делегацией Коммунистической народной партии Казахстана [Электронный ресурс] // Коммунистическая партия Российской Федерации. URL: https://kprf.ru/party-live/regnews/175986.html (дата обращения: 23.02.2020).

${ }^{7}$ В Москве встретились олимпийцы России и Казахстана [Электронный ресурс] // Life.ru. 10.10.2012. URL: https://life.ru/p/676820 (дата обращения: 23.02.2020); Россия и Казахстан 
Муратшина К. Г. Институты гуманитарного сотрудничества между Российской Федерацией и Республикой Казахстан

Особую роль играют межуниверситетские связи. Постепенное расширение контактов российских и казахстанских вузов в 1990-2000-е гг. привело к тому, что сегодня и в РФ, и в РК практически не найти вуза, который бы не имел соглашений о сотрудничестве с университетами страны-партнера и как минимум не осуществлял студенческие обмены и взаимное участие преподавателей и научных сотрудников в конференциях, проводимых научно-образовательными учреждениями двух государств. Кроме того, существует такой институт сотрудничества, как филиалы российских вузов в Казахстане ${ }^{1}$.

Также отдельно следует упомянуть культурную активность диаспор и их общественных объединений ${ }^{2}$. В российских регионах действуют Дома дружбы народов ${ }^{3}$, которые не только проводят культурные мероприятия, но и обеспечивают

будут сотрудничать в подготовке олимпийских кадров [Электронный ресурс] // Евразия Урал. 17.12.2015. URL: http://evrazia-ural.ru/novosti/rossiya-i-kazahstan-budut-sotrudnichatv-podgotovke-olimpiyskih-kadrov (дата обращения: 23.02.2020); Федерации Казахстана, Белоруссии и России обдумывают обжалование правила IWF о трех пробах [Электронный ресурс] // Sports.kz. 25.06.2016. URL: https://www.sports.kz/news/federatsii-kazahstanabelorussii-i-rossii-obdumyivayut-objalovanie-pravila-iwf-o-treh-probah/ (дата обращения: 23.02.2020); Олимпийские комитеты встречаются в Сочи [Электронный ресурс] // Независимое информационное агентство «Кубань». 07.10.2016. URL: http://23rus.org/index.php? $\mathrm{UID}=19909$ (дата обращения: 23.02.2020); Клубы [Электронный ресурс] // Континентальная хоккейная лига. URL: https://www.khl.ru/clubs/ (дата обращения: 23.02.2020).

${ }^{1}$ Филиалы российских вузов [Электронный ресурс] // Посольство Российской Федерации в Республике Казахстан. URL: http://www.rfembassy.kz/tm/russian_mission_in_kazakhstan/ filialy_rossiiskih_vuzov/ (дата обращения: 23.02.2020)

${ }^{2}$ История [Электронный ресурс] // Федерация мигрантов России. URL: http://www.fmronline.ru/history/ (дата обращения: 23.02.2020); В Посольстве Казахстана в Москве прошла встреча с диаспорой [Электронный ресурс]//Федерация мигрантов России. URL: http://www. fmr-online.ru/2016/12/15/v-posolstve-kazahstana-v-moskve-proshla-vstrecha-s-diasporoj/ (дата обращения: 23.02.2020); Литературно-музыкальное мероприятие «Ленинградцы - дети мои!», посвященное 170-летию Джамбула Джабаева, пройдет в Оренбурге [Электронный ресурс] // Федеральное агентство по делам национальностей РФ. 18.03.2016. URL: http://fadn.gov.ru/news/2016/03/18/2672-literaturno-muzykalnoe-meropriyatie-leningradtsydeti-moi-posvyaschennoe-170-letiyu-dzhambula-dzhabaeva-proydet-v-orenburge (дата обращения: 23.02.2020); В Москве пройдет третий Бал кочевых культур [Электронный ресурс] // Федеральное агентство по делам национальностей РФ. 26.05.2016. URL: http://fadn. gov.ru/news/2016/05/26/2793-v-moskve-proydet-tretiy-bal-kochevyh-kultur (дата обращения: 23.02.2020); Организации российских соотечественников в Республике Казахстан [Электронный ресурс] // Посольство Российской Федерации в Республике Казахстан. URL: http://www.rfembassy.kz/tm/russian_mission_in_kazakhstan/organizacii_ros_sootechestvenn/ (дата обращения: 23.02.2020); Информация о текущей деятельности диаспоры [Электронный ресурс] // Посольство Республики Казахстан в Российской Федерации. URL: https://kazembassy.ru/rus/diaspora/tekushaya_deyatelnost/ (дата обращения: 23.02.2020); Список общественных организаций соотечественников в России [Электронный ресурс] // Посольство Республики Казахстан в Российской Федерации. URL: https://kazembassy.ru/rus/ diaspora/spisok_obsh_organizacii (дата обращения: 23.02.2020).

${ }^{3}$ В Челябинской области пройдет фестиваль казахского народного творчества «Туган Жер» [Электронный ресурс] // Федеральное агентство по делам национальностей РФ. 04.08.2016. 
содействие и помощь мигрантам. Аналогичные Дома дружбы народов существуют и в регионах и городах Казахстана ${ }^{1}$.

Отметим, что представители и государственных, и негосударственных структур имеют возможность участия в проводящемся ежегодно с 2003 г. крупнейшем российско-казахстанском форуме приграничного сотрудничества, а также в многосторонних аналогичных мероприятиях, например, Форуме народов России и Евразии ${ }^{2}$.

Таким образом, можно сделать следующие выводы. Мы видим, что гуманитарная сфера во взаимодействии РФ и РК очень хорошо институционализирована, сотрудничество ведется на постоянной основе конкретными акторами на всех уровнях международного взаимодействия. Государственные институты сотрудничества, сформированные еще в 1990-е гг., стали базой для развития самых разных механизмов контактов между обществами двух стран. Главным же актором, без которого не могли бы функционировать все эти институты, являются граждане двух стран, заинтересованные в контактах между собой,-— участники конкурсов студенческих проектов, авторской песни и художественного мастерства, докладчики научных конференций, участники студенческих обменов и молодежных форумов, волонтеры поисковых отрядов в местах боев Великой Отечественной войны. Спектр институтов сотрудничества чрезвычайно разнообразен и отображает длительную традицию взаимодействия народов двух стран, он развивается, множится и вовлекает все новые общественные группы. Вместе с тем наполнение практическим содержанием деятельности каждого института сотрудничества заслуживает отдельных исследований.

\section{Литература}

1. Сыздыкова Ж. С. Евразийская интеграция: от идеи к реальности // Российская тюркология. 2014. № 1(10). С. 62-70.

2. Егоров Д. В. Переосмысливая евразийскую концепцию: проект Евразийского союза Н. А. Назарбаева // Вестник Российского университета дружбы народов. Сер. Политология. 2014. № 1. C. 51-59.

3. Курылев К. П., Станис Д. В. Процесс развития евразийской интеграции: история, современные проблемы и перспективы // Современная наука. 2015. № 2. С. 13-18.

URL: http://fadn.gov.ru/news/2016/08/04/2865-v-chelyabinskoy-oblasti-proydet-festivalkazahskogo-narodnogo-tvorchestva-tuganzher (дата обращения: 23.02.2020); В Свердловской области стало больше мигрантов-нелегалов [Электронный ресурс] // Е1 — городской портал Екатеринбурга. 27.02.2020. URL: https://www.el.ru/news/spool/news_id-68988508.html (дата обращения: 28.02.2020).

${ }^{1}$ Официальный сайт Дома дружбы Костанайской области [Электронный ресурс]. URL: http://www.kostdom.kz/ (дата обращения: 28.02.2020); Областной Дом дружбы [Электронный ресурс] // Управление культуры, архивов и документации Актюбинской области. URL: http://archive.fo/VOjs3\#selection-83.1-83.65 (дата обращения: 28.02.2020); В Уральске открылся Дом дружбы [Электронный ресурс] // Информ-Биржа. 04.02.2016. URL: http://ibirzha.kz/v-uralske-otkrylsya-dom-druzhby/ (дата обращения: 28.02.2020).

22 ноября в преддверии Дня народного единства в Москве состоится первый Форум народов России и Евразии [Электронный ресурс] // Федеральное агентство по делам национальностей РФ. 25.10.2016 URL: http://fadn.gov.ru/news/2016/10/25/2938-2-noyabrya-v-preddveriidnya-narodnogo-edinstva-v-moskve-sostoitsya-pervyy-forum-narodov-rossii-i-evrazii (дата обращения: 23.02.2020).. 
Муратшина К. Г. Институты гуманитарного сотрудничества между Российской Федерацией и Республикой Казахстан

4. Троицкий Е. Ф. Внешняя политика Казахстана: формирование и развитие (19922000 гг.) // Вестник Томского государственного университета. 2010. № 337. С. 96-99.

5. Лушников О. В. Классическое и современное евразийство: проблема преемственности идейного комплекса // Научный Татарстан. 2010. № 3. С. 129-140.

6. Baumann M. Eurasianist rhetoric in Russia and Kazakhstan. Negotiating hegemony through different visions of society // Central Asia and the Caucasus. 2019. Vol. 20. Issue 1. P. 34-43.

7. Кузьмина Е. М. Внешнеэкономические связи Казахстана // ЭКО. 2015. № 9(495). C. $43-54$.

8. Гусев Л. Ю., Казанцев А. А. Российско-казахстанские отношения: проблемы и перспективы // Управленческое консультирование. 2015. № 1(73). С. 29-40.

9. Ветренко И. А., Каппасова Г. М. Акторы региональной современной политики в условиях межгосударственного взаимодействия (на примере России и Казахстана) // Вестник Московского государственного областного университета. Сер. История и политические науки. 2015. № 2. С. 203-211.

10. Лысенко Ю. А. Приграничное сотрудничество Российской Федерации и Республики Казахстан в научно-образовательной сфере // Дневник Алтайской школы политических исследований. 2016. № 32. С. 276-282.

11. Аршинов Ю. Е., Лапенко М. В. Анализ приграничного сотрудничества России и Казахстана в контексте евразийской интеграции (на примере Саратовской области) // Coвременные евразийские исследования. 2015. № 1. С. 43-49.

\title{
INSTITUTIONS OF HUMANITARIAN COOPERATION BETWEEN THE RUSSIAN FEDERATION AND THE REPUBLIC OF KAZAKHSTAN
}

\author{
Ksenia G. Muratshina \\ Cand. Sci. (Hist.), A/Prof., \\ Ural Federal University named after the first President of Russia B. N. Yeltsin \\ 19 Mira St., Ekaterinburg 620002, Russia \\ ksenia.muratshina@urfu.ru
}

Absract. The article analyzes the institutional structure of bilateral cooperation between the Russian Federation and the Republic of Kazakhstan, namely the ties in such areas as culture, education, science, information and mass communications, sports, tourism and youth policy. Based on the study of the processes of bilateral humanitarian cooperation over the past decade (2010-2020), we have considered both governmental and non-governmental institutions, providing contacts between sectoral departments (ministries and agencies), diplomatic representatives, local authorities, non-profit organizations, and diasporas. The research is based on the study of bilateral diplomatic documents, official reports of state authorities, news archives of the Russian and Kazakh mass media, as well as materials of non-governmental organisations.

Keywords: Russia; Kazakhstan; state, society, international relations; humanitarian cooperation; Eurasian integration.

Статья поступила в редакцию 03.03.20; одобрена после редактирования 06.04.20; принята к публикации 30.10 .20 . 